\title{
Exploring the Effects of Islamic Religious Images and Product Quality in Selling Non-Food Products
}

\author{
Dessy Kurnia Sari ${ }^{1}$, Suziana Anas ${ }^{2}$, Vinda Larasintia ${ }^{3}$ \\ ${ }^{1}$ Universitas Andalas, Padang and Indonesia, $₫$ dessysari55@gmail.com \\ ${ }^{2}$ Universitas Andalas, Padang and Indonesia, $₫$ suzianaanas@gmail.com \\ ${ }^{3}$ Universitas Andalas, Padang and Indonesia, $₫$ vindalarasintia14@gmail.com
}

\begin{abstract}
A religious image is often used by marketers to engage and attract prospective clients in a Muslim society. Some Islamic images discussed in this paper include the availability of Muslim product, the store's atmospheric condition, the way sales agents handle customers (humanistic), and the implementation of Islamic value. This study aims to determine the effect of Islamic Religious Images applied in some Indonesian fashion retail stores and determine its impacts on Muslim Consumers' Purchase Decision. The study utilized a Structural Equation Modeling analyzed using a Smart PLS program. A total of two hundred (200) customers perfectly responded to a self-administrated questionnaire used to conduct the study. The results show that Islamic Store Image and Product Quality have significant and positive effects on Muslim Consumers' Purchase Decision. Although product quality is still an important factor to consider, the respondents were elated when a retail store implemented an Islamic value. This managerial implementation would be relevant to marketers targeting Muslim consumers. A broader study in international level would give more insight to these findings.

Keyword: Islamic Store Image; Product Quality; Purchase Decision; Non-food Products
\end{abstract}

\section{Introduction}

Controversy of 'halal hijab' by Zoya in 2016 was only one example about the use of Islamic names and symbols in Indonesian market (Wulan, 2016). Zoya as one of the famous hijab brands in Indonesia proudly communicate to the Indonesian market that the company use 'halal' materials for Muslim women that they call 'halal hijab'. Despite some pros and contras from Indonesian people, the halal certificate has dramatically increased the sales of Zoya's product in 2016 (Wulan, 2016).

Nowadays, the use Islamic symbols are getting more popular. Not only the use of halal logo, but many retail stores also have an Islamic store atmosphere to attract their targeted Muslim consumers including in fashion industries. Store image considered as an important factor in a retail business. Putri (2016), found that store image has a positive and significant influence on purchasing decisions. Another study by Fauzi et al (2016) also confirmed that consumers' purchase decision is influenced by store attributes that were related to religious image. Products define as anything that can be offered to the market to get attention, be bought, used, or consumed that can satisfy desires or needs, (Kotler \& Armstrong, 2012). Muslims consumers may also boycott products that have used an Islamic symbol improperly (Sari et al, 2017). Therefore, marketers would implement a comprehensive marketing strategy, including the use of Islamic atmospheres, in order to attract consumers' attention to buy their products.

Furthermore, consumers would also want to buy products that suit their needs. The quality of a product is one of the important considerations of consumers in making 
purchasing decisions. Hendra (2017), for example, found that product quality has a positive and significant influence on a purchase decision. Therefore, this study would further explore the Effects of Islamic Religious Images and Product Quality in Selling Non-Food Products. While previous study mainly focused on the effect of Islamic religious images in food products, the present study would explore the effects on non-food products. This study would give a significant benefit for a business targeting Muslim consumers and to give better understanding about Muslim market for its readers.

\section{Consumer Behavior and Store Image}

According to Schiffman and Kanuk (2010), consumer behavior is defined as the behavior of using, evaluating, and spending products and services to satisfy their needs. Moreover, Sangadji and Sopiah (2013) claim that consumer behavior is an action that is directly involved in the acquisition, consumption, and expiration of a product or service, including the process that precedes and follows the action. Therefore, marketers need to closely monitor behaviour of consumers especially their target market.

Kotler and Amstrong (2012) define a store image are what consumers think about a store, includes perceptions and attitudes of consumers that are based on the sensation of stimuli on their five senses. Islamic Store Image means that a store is not only provides Muslim products but also pays attention to Islamic values in carrying out its business. Generally, an Islamic retail store's mission is to provide Muslim- made products from trusted sources (Alserhan, 2010). Based on Fauzi et al (2016), Islamic store image have some dimensions such as Muslim product, Islamic store atmosphere, humanistic and Islamic value.

\section{Product Quality}

According to Kotler and Armstrong (2012), product quality is the ability of a product to demonstrate its function, this includes overall durability, reliability, accuracy, ease of operation, and product repairs, as well as other product attributes. From the marketing point of view, quality is measured based on buyer perceptions. Furthermore, Kotler and Armstrong (2009) claim that product quality is mainly based on consumers' perceptions.

\section{Purchase Decision}

Purchase decision is an important concept in marketing. Khuong and Duyen (2016) state that purchasing decisions are a process of integration of consumers that includes the process of evaluates two or more alternatives and making a choice. Marketers in Islamic countries offer an Islamic symbol together with good product quality to influence consumers in making decision in a retail store (Fauzi et al, 2016). Therefore, this study has two hypotheses:

Hypothesis 1: Islamic store image has a significant and positive effect on purchase decision Hypothesis 2: Product quality has a significant and positive effect on purchase decision

\section{Methods}

This study is an explanatory research. According to Sekaran (2006) explanatory is a type of research that shows a relationship between variables tested. The research uses an explanatory survey with a quantitative method. The research would be conducted in a normal environment or commonly called contrived study. The time horizon of this study is cross-sectional because data is only collected in a certain time, in 2018.

Hair et al. (2010), recommend that ideally a good research need to have at least 5-10 samples for each number of item statements on the questionnaire. This study has 39 statements on the questionnaire, meaning the minimum sample is $39 \times 5=195$. This study added 5 people to prevent data shortages and errors. Thus, the number of samples that were 
used in this study are 200 samples. The chosen sample is consumers of the Elzatta Muslim fashion boutique in Padang city, West Sumatran, Indonesia whose ages are started from 16 years old.

\section{Result and Discussion}

The characteristics of the respondents in this study were divided based on gender, occupation, age and income / allowance per month. The questionnaire was distributed to 200 consumers of Elzatta's Muslim fashion boutique in Padang. Table 1 shows that the AVE values are all above 0.50, thus proving that all constructs used in this study have good validity values.

Table 1 Average Variance Extracted (AVE)

\begin{tabular}{lll}
\hline & (AVE) & V AVE \\
\hline Aesthetics & 0.813 & 0.902 \\
\hline Conformance & 0.569 & 0.754 \\
\hline Durability & 0.739 & 0.859 \\
\hline Humanistic & 0.543 & 0.737 \\
\hline Islamic Store Atmosphere & 0.620 & 0.787 \\
\hline Islamic Store Image & 0.512 & 0.716 \\
\hline Islamic Value & 0.628 & 0.792 \\
\hline Muslim Product & 0.513 & 0.716 \\
\hline Perceived Quality & 0.769 & 0.877 \\
\hline Performance & 0.593 & 0.770 \\
\hline Product Quality & 0.517 & 0.719 \\
\hline Purchase Decision & 0.553 & 0.744 \\
\hline Reliability & 0.703 & 0.838 \\
\hline
\end{tabular}

Another method used to assess discriminant validity is to look at the square root of the AVE for each construct whether it is greater than the correlation between constructs and other constructs. Table 2 shows that the composite construct reliability has a value above 0.70 so that the constructs used to be measured are reliable.

Table 2 Composite Reliability

\begin{tabular}{ll}
\hline & $\begin{array}{l}\text { Composite } \\
\text { Reliability }\end{array}$ \\
\hline Aesthetics & 0.897 \\
\hline Conformance & 0.798 \\
\hline Durability & 0.895 \\
\hline Humanistic & 0.824 \\
\hline $\begin{array}{l}\text { Islamic Store } \\
\text { Atmosfer }\end{array}$ \\
\hline Islamic Store Image & 0.829 \\
\hline Islamic Value & 0.839 \\
\hline Muslim Product & 0.834 \\
\hline
\end{tabular}


Table Cont...

\begin{tabular}{ll}
\hline Perceived Quality & 0.869 \\
\hline Performance & 0.812 \\
\hline Product Quality & 0.895 \\
\hline Purchase Decision & 0.787 \\
\hline Reliability & 0.876 \\
\hline
\end{tabular}

Furthermore, Table 3 shows that the Adjusted R-square of the purchase decision is 0.300 . It means that $30 \%$ of the variables that influence the purchase decision are Islamic store image and product quality while the remaining $70 \%$ is explained by other variables outside the research model.

Table 3 R Square

\begin{tabular}{lll}
\hline & R Square & $\begin{array}{l}\text { Adjusted } \\
\text { R square }\end{array}$ \\
\hline Purchase Decision & 0.307 & 0.300 \\
\hline
\end{tabular}

The hypothesis testing was looking at the value of $t$-statistics because SmartPLS uses nonparametric tests to determine the significance level of path coefficient where $t$-statistical values are generated by running the bootstrapping algorithm on SmartPLS 3. The hypothesis will be accepted if the t-statistic value exceeds t-table value is 1.65 (Ghozali\&Lathan, 2012). Table 4 shows the result of the hypothesis testing in which both of the hypotheses in this study are supported.

Table 4 hypothesis testing

\begin{tabular}{clccc}
\hline Hypotheses & \multicolumn{1}{c}{ Relationship } & $\begin{array}{c}\text { Path } \\
\text { Coefficient }\end{array}$ & t-statistic & Result \\
\hline H1 & $\begin{array}{l}\text { Islamic Store Image-> } \\
\text { Purchase Decision }\end{array}$ & 0.183 & 2.302 & Supported \\
\hline H2 & $\begin{array}{l}\text { Product Quality-> Purchase } \\
\text { Decision }\end{array}$ & 0.433 & 5.790 & Supported \\
\hline
\end{tabular}

\section{The Influence Islamic Store Image and Purchase Decision}

The first hypothesis (H1) shows that the Islamic store image is positively and significantly influence consumers' purchase decision. Store image is an image created by the store so that it describes what is seen and felt by consumers of the store, consumer image of a store consists of exterior and interior impressions (Fauzi, 2016). The finding is in line with a study of Shamsher (2016) which found that the creation of an image for a store that also means an ability to develop artistic values of a store environment would trigger purchase decision of consumers. In consumers' perspective, a proper Islamic store means the store should has an Islamic image, halal certification with trusted process and having an atmosphere that emphasizes on Islamic aesthetic values (Fauzi et al ,2016).

Finding of the present study is also in line with a study of Shamsher (2016), that store image has a positive and significant influence on purchasing decisions. Another study of Fauzi et al (2013) regarding retail store attributes in Islamic perspectives of Muslim consumers in Malaysia also found something similar. Moreover, another research that was conducted by Fauzi, et al (2016) shows that the Islamic Store Image has a significant influence on consumers' purchase decisions. This means that the influence of the Islamic store image is significant on purchase decision. 


\section{The Influence Product Quality and Purchase Decision}

The results of the second hypothesis show that the effect of product quality on the purchase decision of Muslim fashion boutique in Padang is also positive and significant which means the second hypothesis is supported. According to Kotler and Armstrong (2004), product quality is the ability of a product to perform its function. This includes overall product durability, reliability, accuracy, ease of operation and repair, and other valuable attributes. In line with this study, Hendra (2017) also found that product quality significantly influences consumers purchase decision.

\section{Conclusion}

There are some conclusions in the present research as follows:

1. There is a positive and significant relationship between Islamic store image and purchase decision of Muslim consumers in a Muslim fashion boutique. It means Islamic image does not only successfully influence consumers in buying food but also non-food products. The result shows that when the respondent decides to buy something, they will pay attention to the image of a retail store. It also influences consumers' purchase decision. Consumers will be buying more when they feel comfortable with a store image. More specifically, respondents pay attention on how the Islamic atmosphere in a store, the way sales people serve respondents, such as the way the staff say Assalamualaikum in greeting a consumer has some influence on consumers' purchase decision.

2. The second hypothesis test results also show that there is a positive and significant relationship between product quality and purchase decision at a Muslim fashion boutique. It means that the respondent decides to buy a product because of the quality of the product.

Implication of the Research

A retail store needs to improve the Islamic image such as playing Islamic songs, improve services based on Islamic values by offer a comprehensive training to their salespeople. Another strategy for a retail store is to increase product quality such as having more products that is in line with Islamic standards. Those two strategies might increase consumers' purchase decision.

\section{Future Research}

Future research may compare Muslim consumers in other Muslim countries and in non -Muslim countries. It would be interesting to see how Muslim consumers in two different countries evaluate Islamic Image and product quality in making purchase decision. It would also be a good idea to compare Muslim and other religious followers (such as Christian) in responding to religious image in a retail store.

\section{References}

Alserhan, B. A. (2010). On Islamic branding: brands as good deeds. Journal of Islamic Marketing, 1(2), 101-106

Alfred, O. (2013). Influences of Price And Quality On Consumer Purchase Of Mobile Phone In The Kumasi Metropolis In Ghana A Comparative Study. European Journal of Business and Management.

Amron, A. (2018). The Influence of Brand Image, Brand Trust, Product Quality, and Price on the Consumer's Buying Decision of MPV Cars. European Scientific Journal, 14(13), 228239. https://doi.org/10.19044/esj.2018.v14n13p228

Fauzi, A. (2016). Pakaian Wanita Muslimah Dalam Perspektif Hukum Islam Pendahuluan. Jurnal Ekonomi Syariah. 
Fauzi, W. I. M., Muhammad, N., Mokhtar, S. S. M., \& Yusoff, R. Z. (2016). What motivate muslim consumer to patronage islamic based-retail store? International Review of Management and Marketing, 6(7Special Issue), 199-203. https://doi.org/10.1016/j.jretconser.2014.04.008

Ghozali, Imam \& Latan, Hengky. (2012). Partial Least Aquares Konsep, Teknik dan Aplikasi Smart PLS 2.0. Semarang: Universitas Diponegoro.

Gunadi, N. P. (2015). The Influence of Product Quality and Consumer Perception to Purchase Decision on Canon DLSR Camera in Manado. Jurnal EMBA, 3(1), 212- 219.

Hair, JR. (2010).Multivariate Data Analysis. New Jersey:Prentice Hall.

Hendra, L. (2017). Impact of Brand Image, Product Quality and Self-Efficacy on Purchase Decisions on Private Label Rights Products. An Empirical Study. Expert Journal of Business and Management.

Irani, W., Fauzi, M., Sanuri, S., Mokhtar, M., \& Sharif, S. (2013). Retail Store Attributes In Islamic Perspectives. School of Business Management, 287-296.

Kotler, P and Armstrong, G. (2004), Principles of Marketing, Pretince Hall, Upper Saddle River, NJ.

Kotler, P, Keller,K. L. (2012). Marketing Management 13 New Jersey : Prentice Hall. Sangadji, E. M., \& Sopiah, 2013. Consumer Behavior: Perilaku Konsumen dan Strategi Pemasaran Jilid 2. Jakarta: Erlangga.

Sari, D.K, Mizerski,D \& Liu,F. (2017). Boycotting foreign products: a study of Indonesian Muslim consumers, Journal of Islamic Marketing, 8 (1),pp. 16-34, doi: 10.1108/JIMA-122014-0078

Schiffman, Leon, Kanuk, L. L. (2010). Consumer Behavior $9^{\text {th }}$ edition. New Jersey: Prentice-Hall. Sekaran, Uma. (2006). Research Method for Business. Jakarta: Salemba Empat.

Sekaran, U. (2011). Metode Penelitian Untuk Bisnis. Jakarta : Salemba Empat.

Shamsher, R. (2016). Store image and its impact on consumer behavior. ELK Asia Pacific Journal of Marketing and Retail Management, 7(2), 1-27. https://doi.org/10.16962/EAPJMRM/issn.

State of the Global Islamic Economy 2014-2015 Report. (2015). State of the Global Islamic Economy 2014-2015 Report. Thomson Reuters and DinarStandard. https://doi.org/10.1017/CBO9781107415324.004.

Wulan, R. (2016). Imbas Sertifikat Kerudung Halal terhadap Penjualan Produk Zoya, Available at https://www.dream.co.id/lifestyle/imbas-sertifikat-kerudung-halalterhadap-penjualan-produk-zoya-160210o.html Retrieved 10th of January 2019 